\title{
Peertechz
}

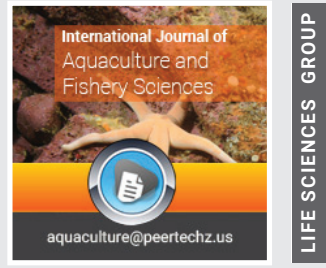

\section{Age and growth increment of Labeo calbasu (Hamilton 1822) from the Vindhyan region,} Central India

Received: 26 April, 2021

Accepted: 12 May, 2021

Published: 13 May, 2021

*Corresponding authors: Amitabh Chandra Dwivedi, Department of Zoology, Nehru Gram Bharati (Deemed to be University), Prayagraj, Uttar Pradesh, India, E-mail: saajjjan@rediffmail.com

Keywords: Labeo calbasu; Mean length; Age and growth; Bundelkhand region

https://www.peertechz.com

\author{
Amitabh Chandra Dwivedi ${ }^{1 *}$ and Prakash Nautiyal ${ }^{2}$ \\ 'Department of Zoology, Nehru Gram Bharati (Deemed to be University), Prayagraj, Uttar Pradesh, India \\ ${ }^{2}$ Department of Zoology, H.N.B. Garhwal University Srinagar, Garhwal-246174, Uttrakhand, India
}

\begin{abstract}
Labeo calbasu is an important game fish in the ponds and reservoirs where it can be cultivate along with Indian major carp and exotic major carp. The present study provides comparative information of age and growth of $L$. calbasu. Age and growth increment was recorded by obtaining samples of Labeo calbasu during $2003-2004$ from the fish market along the Ken river, Paisuni river and Tons river (Bundelkhand region). The age of fishes was recorded to be $6+$ in the Ken river, $5+$ in the Paisuni river while $7+$ in the Tons river. The formation of growth ring occurred annually. The maximum mean length $21.3 \mathrm{~cm}$ was recorded for in $1+$ age from the Paisuni river. Overall, mean length of fishes for $2+, 3+, 4+, 5+$ and $6+$ age groups was recorded higher in the Tons river compared to Paisuni and Ken rivers. Hence, the Tons river is more suitable for the growth of $L$. calbasu.
\end{abstract}

\section{Introduction}

Labeo calbasu is a medium size freshwater fish species belonging to the family Cyprinidae under the order Cypriniformes and is an ecologically significant (example habitat restoration, manage keystone species and maintain food web) for both commercial and recreational fisheries in tropical and sub-tropical waters. Labeo rohita, L. calbasu and L. bata species are very frequently appearing in the lotic ecosystem in the Indian subcontinent. The second most important of these is the L. calbasu which has a very wide distribution, formed choiceable fishery and resistant to disease. L. calbasu supports an important commercial fishery in the rivers (Example Ganga, Yamuna, Narmada, Godavari, Ken, Paisuni and Tons), wetlands, dams, lakes and reservoirs of India [1-6]. L. calbasu is a riverine fish especially in India, Pakistan, Bangladesh, Myanmar and Nepal but also well established in many large natural water bodies [7-10] and are able to tolerate a wide range of environmental conditions (example temperature, pollution). It is also culture with Indian major caps group fishes (Catla catla, Labeo rohita and Cirrhinus mrigala) and also exotic major carp fishes (Ctenopharyngodon idella, Hypophthalmichthys molitrix and Cyprinus carpio) in India, Bangladesh and Pakistan [11-13]. It is a bottom feeder in habit with harbivour. Accurate fish growth rates are important for growth analysis, age structure analysis and mortality rate estimation. The information of fish age and growth increment is also necessary to perceptive a species life history, reproductive biology, population dynamics, biomass and fisheries sustainability [8,14-18].

Fish are very diverse animals and can be categorized in many ways in form of biology. The age and growth study was conducted by [19] from the Ganga river [20] from the Yamuna river [21] from the Ganga and Yamuna rivers [22] from the Ghaghra river. But nothing is known for the Ken, Paisuni and Tons rivers that are a part of the Ganga river system in the Ganga Plains, India.

\section{Material and methods}

Present study was conducted from the three rivers namely Ken, Paisuni and Tons rivers, Bundelkhand region, India (Map 1). The Ken and Paisuni rivers are right bank tributary of the 
Yamuna river while the Tons river is a right bank tributary of the Ganga river. Fish samples of L. calbasu were collected seasonally during 2003-2004 from the Ken, Paisuni and Tons rivers. The scale method has been used for estimation of age and growth in the present investigations. The key scales were removed from the row above lateral line and below dorsal fin region [23-26]. The scales were cleaned in 5\% $\mathrm{KOH}$ solution to remove adhering- tissues and finally washed in distilled water. The scales were then pressed while drying in order to avoid their curling. The season with "minimum width in the terminal part of the anterior field of the scale" was designated as the period of ring formation. Since this condition occurred only once a year, the ring was designated as annuli. The total length and growth rate were recorded as differences betweenat-age.

\section{Result and discussion}

The formation of growth ring occurred annually. The ring formation was closed with increasing of fish age in all fishes (Plate 1 ). The fishes of $1+$ to $5+, 1+$ to $6+$ and $1+$ to $7+$ age groups were recorded in the Paisuni river, Ken river and Tons river, respectively (Table 1). Labeo calbasu is slow growing riverine fish. The key scales depicting different age are presented in Plate 2. The differences in growth may be observed when same species inhabit different rivers of the same ecoregion. The mean

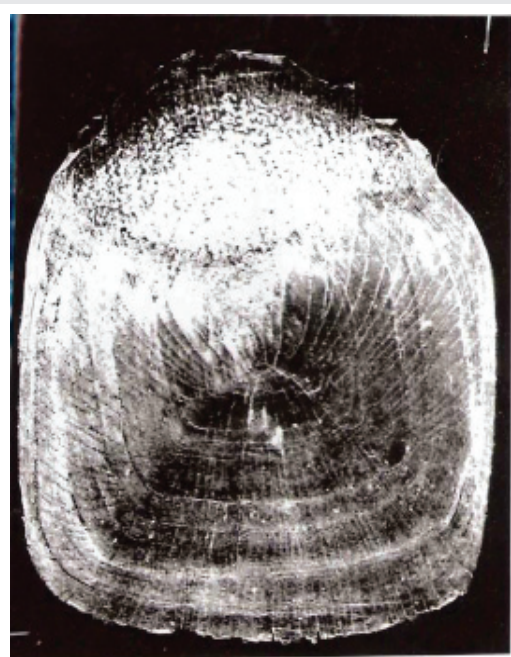

Platec 1: Transparent and opeque zone in the scale of $L$. calbasu and growth ring appearance closed with increasing of fish age. length was maximum in juvenile stage (1+ age group) in the Paisuni river compared to Tons and Ken rivers. The maximum growth rate was recorded in the Tons river in adult and old stock (Table 1). The growth compensation was recorded in 6+ age class form Tons river fishes. The growth rate was observed $19.2,11.5,7.7,5.4,3.4$ and $2.3 \mathrm{~cm}$ for $1+$ to $6+$ age groups in the Ken river. The growth rate recorded for the Paisuni river was $21.3,10.5,7.7,3.2$ and $1.9 \mathrm{~cm}$ from $1+$ to $5+$ age groups. Similarly in the Tons river 20.9, 11.8, 7.5, 6.7, 4.5, 3.1 and 3.5 $\mathrm{cm}$ from $1+$ to $7+$ age was observed (Table 1 ). These growth rates indicated that the ecological condition of the Tons river was most suitable for the growth of L. calbasu.

The maximum growth percentage of $L$. calbasu was recorded in first year in the Paisuni river $(47.76 \%)$ compared to Ken river $(38.79 \%)$ and Tons river $(36.03 \%)$ (Figure 1$)$. The growth percentage varied from age to age and river to river (Figure 1). The lowest growth percentage was recorded in $5+$ age group (4.26\%) from the Tons river. The growth compensation was estimated from the Tons river in $6+$ age group and difference was $0.69 \%$ (Figure 1 ). The growth rate of fishes was not found in systematic order (increasing or decreasing order). The fluctuations in fish length indicate the fish growth, compensation. It is very common in almost all natural stocks of fishes (fresh water, brackish water and marine water).

In case of scales the study of annual growth is based on the fact that most temperate and the sub-arctic fishes of Northern and Southern continents have their rate of metabolism and therefore growth strongly influenced by the seasonal variations. Summer is a period of activity resulting in brisk and fast or heavy growth and winter a period of slow or no growth resulting in differential growth and thus deposition of layers forming alternating growth zones, year after year [27]. It is for these reasons that the use of scales for age determination is most reliable for temperate fishes. On the other hand, in tropics, temperature is uniform throughout the year, daylight is fairly constant and fish tend to spawn several times in a year, besides, the occurrence of wide fluctuations in food composition and chemical composition of water due to the rains, organic load and floods. Thus, the fish inhabiting tropical regions show growth rings, which do not necessarily represent year marks. In the tropical regions, the annuli develop as result of cessation of growth during unfavourable periods such as poor availability of food caused by various factors like low water level or maturation of the gonads $[28,29]$.

Table 1: Mean length and growth rate of Labeo calbasu at various ages estimated by scale methods from the Ken, Paisuni and Tons rivers, Bundelkhand region, India.

\begin{tabular}{|c|c|c|c|c|c|c|c|c|c|}
\hline \multirow[t]{2}{*}{ Age } & \multicolumn{3}{|c|}{ Ken river } & \multicolumn{3}{|c|}{ Paisuni river } & \multicolumn{3}{|c|}{ Tons river } \\
\hline & $\begin{array}{l}\text { Mean length } \\
\text { (cm) }\end{array}$ & $\begin{array}{l}\text { Growth rate } \\
\text { (cm) }\end{array}$ & $\begin{array}{l}\text { Von Bertalanffy's fit } \\
(\mathrm{cm})\end{array}$ & $\begin{array}{l}\text { Mean length } \\
(\mathrm{cm})\end{array}$ & $\begin{array}{l}\text { Growth rate } \\
(\mathrm{cm})\end{array}$ & Von Bertalanffys fit (cm) & $\begin{array}{l}\text { Mean length } \\
(\mathrm{cm})\end{array}$ & $\begin{array}{l}\text { Growth rate } \\
(\mathrm{cm})\end{array}$ & $\begin{array}{l}\text { Von Bertalanffy's } \\
\text { fit (cm) }\end{array}$ \\
\hline $1+$ & 19.2 & 19.2 & 19.7 & 21.3 & 21.3 & 21.6 & 20.9 & 20.9 & 21.6 \\
\hline $2+$ & 30.7 & 11.5 & 31.1 & 31.8 & 10.5 & 32.2 & 32.7 & 11.8 & 33.4 \\
\hline $3+$ & 38.4 & 7.7 & 38.8 & 39.5 & 7.7 & 40.2 & 40.2 & 7.5 & 40.8 \\
\hline $4+$ & 43.8 & 5.4 & 44.2 & 42.7 & 3.2 & 43.1 & 46.9 & 6.7 & 47.3 \\
\hline $5+$ & 47.2 & 3.4 & 47.9 & 44.6 & 1.9 & 45.1 & 51.4 & 4.5 & 51.7 \\
\hline $6+$ & 49.5 & 2.3 & 50.2 & & & & 54.5 & 3.1 & 54.2 \\
\hline $7+$ & & & & & & & 58.0 & 3.5 & 58.4 \\
\hline
\end{tabular}

Citation: Dwivedi AC, Nautiyal P (2021) Age and growth increment of Labeo calbasu (Hamilton 1822) from the Vindhyan region, Central India. Int J Aquac Fish Sci 7(2): 010-013. DOI: https://dx.doi.org/10.17352/2455-8400.000067 

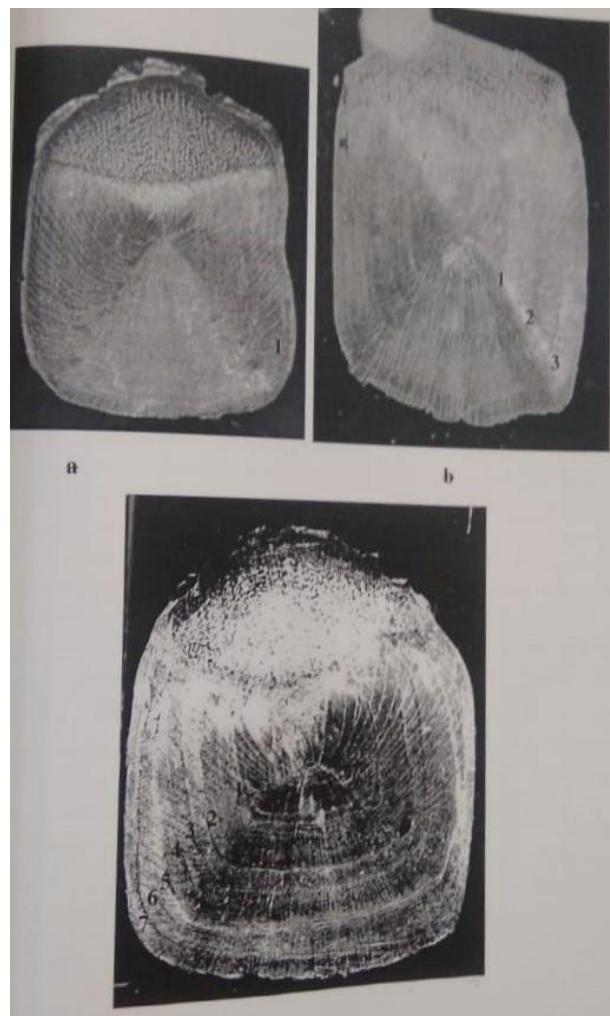

Platec 2: The key scale from the dorsal fin region depicting age of Labeo calbasu a- $1+$ age

b- $3+$ age

c- $7+$ age

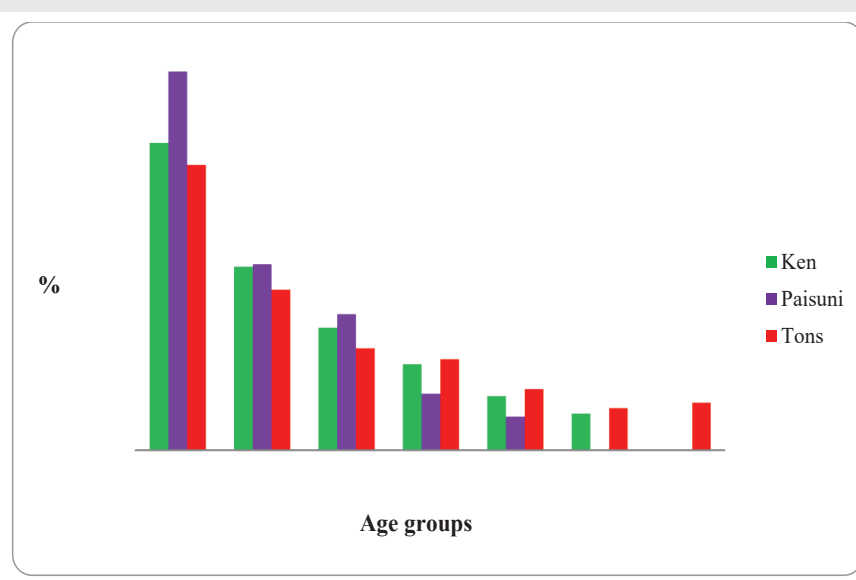

Figure 1: Growth increment (\%) of L. calbasu from the Ken, Paisuni and Tons rivers, Bundelkhand region, India.

The productivity of aquatic ecosystems influences the age and growth, stock and size structure of the fishes [19,30-31] was recorded mean length of L. calbasu of 188.5, 291.0, 381.0, $468.5,543.5,618.5,681.0$ and $731.0 \mathrm{~mm}$ for $1^{\text {st }}$ to eight years of the life cycle, respectively from the Yamuna river at Allahabad [21] recorded more or less similar findings in L. calbasu from the Yamuna and Ganga rivers at Allahabad. Several factors can account for the fluctuation in the growth rate as like quantity and quality of available food, richness of species, density of exotic species (Example especially Cyprinus carpio and Oreochromis niloticus) quality of the water (Example organic load, heavy metal concentration) and maturity [32-40].
Our findings very clearly indicated that the age and growth increment of L. calbasu was different between habitats. Habitat variation in the age and growth of L. calbasu are generally reported.

\section{References}

1. Rizvi F, Dwivedi AC, Singh KP (2010) Study on population dynamics of Labeo calbasu (Ham.), suggesting conservational methods for optimum yield. Natl Acad Sci Lett 33: 247-253. Link: https://bit.ly/3ftM91V

2. Chondar SL (1999) Biology of finfish and shellfish. SCSC Publishers (India) Howrah 1-514. Link: https://bit.ly/33F2kUs

3. Tripathi S, Gopesh A, Dwivedi AC (2017) Fish and fisheries in the Ganga river current assessment of the fish community, threats and restoration. J Exp Zool India 20: 907-912. Link: https://bit.ly/3tHwDEG

4. Sheikh M, Laghari MY, Lashari PK, Khuharo AR, Narejo NT (2019) Status of Labeo calbasu at Lower Indus River Region, Sindh, Pakistan. Sindh Univ Res Jour (Sci. Ser.) 51: 507-512. Link: https://bit.ly/3w1QuQu

5. Khatun MH, Lupa ST, Rahman MF, Barman PP, Liq Q (2019) Evaluation of Labeo calbasu fishery status using surplus production models in Kaptai reservoirs, Bangladesh. Applied Ecology and Environmental Research 17: 2519-2532. Link: https://bit.ly/33KXIRX

6. Nautiyal P, Dwivedi AC (2019) Fishery in the tributaries of Yamuna river (Ken river, Paisuni river) and Ganga river (Tons river). J Mountain Res 14: 19-36. Link: https://bit.ly/3eMAEU9

7. Dwivedi AC, Nautiyal P (2010) Population dynamics of important fishes in the Vindhyan region, India. LAP LAMBERT Academic Publishing $\mathrm{GmbH}$ \& Co. KG, Dudweiler Landstr. 99, 66123 Saarbrucken, Germany 220. Link: https://bit.ly/3uMEFNJ

8. Dwivedi AC, Nautiyal P (2012) Stock assessment of fish species, Labeo rohita, Tor tor and Labeo calbasu in the rivers of Vindhyan region, India. J Environ Biol 33: 261-264. Link: https://bit.ly/33BNuOL

9. Imran S, Thakur S, Jha DN, Dwivedi AC (2015) Size composition and exploitation pattern of Labeo calbasu (Hamilton 1822) from the lower stretch of the Yamuna river. Asian Journal of Bio Science 10: 162-164. Link: https://bit.ly/3bnbkSx

10. Malik S, Qadri AH, Laghari MY, Lashari PK, Kalhoro H, et al. (2019) Growth pattern and morphological variation of Labeo calbasu found in Indus River, Sindh-Pakistan. Journal of Fisheries Science 1: 20-25. Link: https://bit.ly/3hqmhGy

11. Jha DN, Joshi KD, Dwivedi AC, Mayank P, Kumar M, et al. (2015) Assessment of fish production potential of Chitrakoot district, Uttar Pradesh. Journal of the Kalash Science 3: 7-10. Link: https://bit.ly/3vTKeds

12. Dwivedi AC, Mayank P, Tripathi S, Tiwari A (2017) Biodiversity: the non-natives species versus the natives species and ecosystem functioning. $J$ Biodivers Biopros Dev 4. Link: https://bit.ly/33FfReM

13. Vikas A, Mallik S, Chennuri S, Rao BM, Kumar S, et al. (2018) A multivariate morphometric investigation to delineate the stock structure of Labeo calbasu (Cypriniformes - Cyprinidae). Journal of Entomology and Zoology Studies 6: 632-638. Link: https://bit.ly/3oegLrP

14. Haroon AKY, Razzaque MA, Dewan S, Amin SMN, Rahman SL (2001) Population dynamics and stock assessment of Labeo rohita (Ham.), L. calbasu (Ham.) and L. gonius (Ham.) from the Mymensingh basin, Bangladesh. J Biol Sci 1: 671- 675. Link: https://bit.ly/3tHOSK3

15. Ujjania NC, Soni N, Sharma LL (2014) Determination of age and growth of cyprinid fish of tropical environment using scales-A protocol. Fishing Chimes 34: 51- 56. 
16. Ujjania NC, Sharma LL, Srivastava RM (2013) Assessment of age and growth of exotic fish tilapia (Oreochromis mossambicus P.) in lake Jaisamand India. Indian Journal of Fundamental and Applied Sciences 3: 27-34. Link: https://bit.ly/3y9yRA7

17. Mayank P, Tyagi RK, Dwivedi AC (2015) Studies on age, growth and age composition of commercially important fish species. Cirrhinus mrigala (Hamilton, 1822) from the tributary of the Ganga river, India. European Journal of Experimental Biology 5: 16-21. Link: https://bit.ly/3tCj9de

18. Vilizzi L, Copp GH (2017) Global patterns and clines in the growth of common carp Cyprinus carpio. Journal of the Fish Biology. Link: https://bit.ly/3el1r3S

19. Gupta SP, Jhingran AG (1973) Ageing Labeo calbasu (Hamilton) through its scale. Journal of the Inland Fisheries Society India 5: 126-128.

20. Imran S, Jha DN, Thakur S, Dwivedi AC (2015) Age structure of Labeo calbasu (Hamilton 1822) from the river Yamuna. Journal of the Inland Fisheries Society of India 47: 81-85. Link: https://bit.ly/3uOaDsY

21. Singh PR (1999) Fishery biology of Labeo calbasu (Hamilton). D. Phil thesis submitted to the University of Allahabad, Allahabad.

22. Dwivedi AC, Mayank P, Khan S, Tewari NP, Masud S (2010) Studies on the age and growth of Labeo calbasu (Hamilton) with an exploitation pattern from the Ganga River System, Uttar Pradesh (India). Journal of Current Sciences 15 $53-60$

23. Bagenal TB, Tesch FW (1978) Age and growth. In: Bagenal TB (ed) Methods for assessment of fish production in freshwater, 3rd edn. Blackwell Scientific Publication, Oxford, UK 101-136.

24. Nautiyal P, Dwivedi AC (2020) Growth rate determination of the endangered Mahseer, Tor tor (Hamilton 1822) from the Bundelkhand region, Central India. Journal of the Kalash Science 8: 1-6. Link: https://bit.ly/3obdCJv

25. Dwivedi AC, Pathak RK (2018) Age, growth and age pyramid of exotic fish species Oreochromis niloticus (Linnaeus 1758) from the lower stretch of the Yamuna river, India. National Academy Science Letter 41: 345-348. Link: https://bit.ly/33BQP07

26. Dwivedi AC, Mayank P (2013) Studies on the age, growth pattern and sex ratio of Cyprinus carpio var. communis from the largest tributary of the Ganga river, India. Journal of the Kalash Science 21-27. Link: https://bit.ly/3bpRc26

27. Nikolskii GV (1980) Theory of Fish Population Dynamics as the Biological Background for Rational Exploitation and Management of Fishery Resources. Bishen Singh Mahendra Pal Singh Dehra Dun (India) and Otto Koeltz Science Publishers Kooenigstein, W. Germany 1-323.

28. Menon MD (1953) The determination of age and growth of fishes of tropical and subtropical waters. J Bombay Nat Hist Soc 51: 623-635

29. Chugnova NI (1963) Handbook for the Study of Age and Growth of Fishes (English translation). Publishers National Science Foundation Washington $1-132$

30. Mayank P, Dwivedi AC (2017) Resource use efficiency and invasive potential of Non-Native fish species, Oreochromis niloticus from the Paisuni River, India. Poultry Fisheries \& Wildlife Sciences 5. Link: https://bit.ly/3hn19RK

31. Ujjania NC, Sharma LL, Saini VP (2020) Congenial aquatic environment and population establishment of exotic fish tilapia (Oreochromis mossambicus $\mathrm{P}$. 1852) in Jaisamnd Lake, India. Journal of Entomology and Zoology Studies 8 : 1670-1673. Link: https://bit.ly/33DsFIF

32. Nautiyal P (1990) Growth rate and age composition in relation to fishery, feeding and breeding ecology. In: Proc. 2nd Asian Fisheries Forum 769-772, R. Hirano and I. Hanyu (Eds.), Tokyo, Asian Fisheries Society, Manila.
33. Mayank P, Dwivedi AC (2015) Biology of Cirrhinus mrigala and Oreochromis niloticus. LAP LAMBERT Academic Publishing $\mathrm{GmbH}$ \& Co. KG, Dudweiler Landstr. 99, 66123 Saarbrucken, Germany 188. Link: https://bit.ly/33IB0o4

34. Dwivedi AC, Nautiyal P, Joshi KD (2011) Sex ratio and structure of certain cyprinids of Vindhyan region in Central India. Journal of the Inland Fisheries Society of India 43: 77-82. Link: https://bit.ly/3odJHQX

35. Dwivedi AC, Mayank P (2018) Suitability of ecosystem determination through biology and marketing of exotic fish species, Oreochromis niloticus (Linnaeus, 1757) from the Ganga River, India. Journal of Aquatic Research and Marine Sciences 1: 69-75. Link: https://bit.ly/3fg9mUW

36. Tiwari A, Dwivedi AC, Mayank P (2016) Time scale changes in the water quality of the Ganga River, India and estimation of suitability for exotic and hardy fishes. Hydrology Current Research 7: 254. Link: https://bit.ly/3fg9vHY

37. Dwivedi AC, Khan S, Mayank P (2017) Stressors altering the size and age of Cirrhinus mrigala (Hamilton, 1822) from the Ghaghara River India. Oceanography Fish Open Access Journal 4: 555642. Link: https://bit.ly/3eJqwuY

38. Mishra N, Dwivedi AC (2020) Environmental derivers supports to distribution, composition and biology of Cyprinus carpio (Linnaeus, 1758) in respect of time scale: A review. Journal of the Kalash Science 8: 91-102.

39. Dwivedi AC, Mishra N (2021) Age structure of non-native fish species, Cyprinus carpio (Linnaeus, 1758) from the tributary of the Ganga river, India. Journal of Aquaculture \& Marine Biology 10: 76-79. Link: https://bit.ly/2SDxXel

40. Dwivedi AC (2006) Age structure of some commercially exploited fish stocks of the Ganga river system (Banda-Mirzapur section). Thesis submitted to Department of Zoology, University of Allahabad, Prayagraj, (Uttar Pradesh) 138.

Discover a bigger Impact and Visibility of your article publication with

Peertechz Publications

Highlights

* Signatory publisher of ORCID

* Signatory Publisher of DORA (San Francisco Declaration on Research Assessment)

* Articles archived in worlds' renowned service providers such as Portico, CNKI, AGRIS, TDNet, Base (Bielefeld University Library), CrossRef, Scilit, J-Gate etc.

* Journals indexed in ICMJE, SHERPA/ROMEO, Google Scholar etc.

* OAI-PMH (Open Archives Initiative Protocol for Metadata Harvesting)

* Dedicated Editorial Board for every journa

* Accurate and rapid peer-review process

* Increased citations of published articles through promotions

* Reduced timeline for article publication

Submit your articles and experience a new surge in publication services (https://www.peertechz.com/submission).

Peertechz journals wishes everlasting success in your every endeavours.

Copyright: ( 2021 Dwivedi AC, et al. This is an open-access article distributed under the terms of the Creative Commons Attribution License, which permits unrestricted use, distribution, and reproduction in any medium, provided the original author and source are credited. 